\title{
The candelabra tree (Euphorbia ingens): a source of water for black rhinoceros in Liwonde National Park, Malawi
}

\section{C.O. DUDLEY}

Dudley, C.O. 1997. The candelabra tree (Euphorbia ingens): a source of water for black rhinoceros in Liwonde National Park, Malawi. Koedoe 40(1): 57-62. Pretoria. ISSN 0075-6458.

The introduction of two rhinoceros into a $15 \mathrm{~km}^{2}$ fenced sanctuary within Liwonde National Park provided an opportunity for close observation of the animals feeding on the toxic succulent Euphorbia ingens. Feeding invariably caused the death of the plant and for plants with basal diameters between 5-17 cm, mortality ranged from 40-90\%. During the severe drought of 1994 rhinoceros did not drink from the artificial waterhole from approximately 15 July to at least 23 September. As this waterhole was the only source of free water it is believed that the rhinoceros obtained their water from browsing on $E$. ingens.

Key words: black rhinoceros, Euphorbia ingens, Liwonde National Park, Malawi, drought conditions, browsing, toxic plants, plants as water source.

C.O. Dudley, National Herbarium and Botanical Gardens, P.O. 528, Zomba, Malawi.

\section{Introduction}

Two black rhinoceros (Diceros bicornis minor) from the Kruger National Park in South Africa were introduced into Liwonde National Park on 27 October 1993. This marked the reintroduction of the species to Malawi where it was officially declared extinct in 1990 .

Liwonde National Park lies in the southern part of the Malawi Rift Valley, just south of Lakes Malawi and Malombe. The park's vegetation cover is principally a complex of mopane woodland communities growing on extremely flat, ancient alluvial and lacustrine deposits of very compact and impermeable sandy clay soils. Several major seasonal streams pass through the park to join the south flowing Shire River on the park's western edge. Associated with these streams are poorly drained tall grass tree savannas and riverine semi-deciduous forest/thickets. To the north are three small areas of drought deciduous forest/thicket (Dudley 1994).
After a period of acclimatisation in a small boma, the rhinoceros were released into a $15 \mathrm{~km}^{2}$ fenced sanctuary within the park. The sanctuary is located in an area that is predominantly mopane (Colophospermum mopane) woodland with a variety of other species such as Dalbergia melanoxylon. Euphorbia ingens, Albizia anthelmintica, and $A$. harveyi in the understorey. The Ntangai River cuts through the middle of this sanctuary and has on its banks a riverine forest/thicket which is characterised by tall trees such as Terminalia zambesiaca, Cordyla africana, Khaya anthotheca, and Diospyros mespiliformis with an understorey of Friesodleisia obovata, Markhemia and Diospyros spp. The tall grass tree savanna of the river's adjacent floodplain supports a variety of tall grasses (1.5-2.5 m) including Digitaria milanjiana, Hyparrhenia filipendula, Panicum maximum, Setaria sphacelata and Sorghastrum bipennatum and scattered large trees $(15-25 \mathrm{~m})$ such as Acacia nigrescens, Sclerocarya birrea, and Xeroderris 


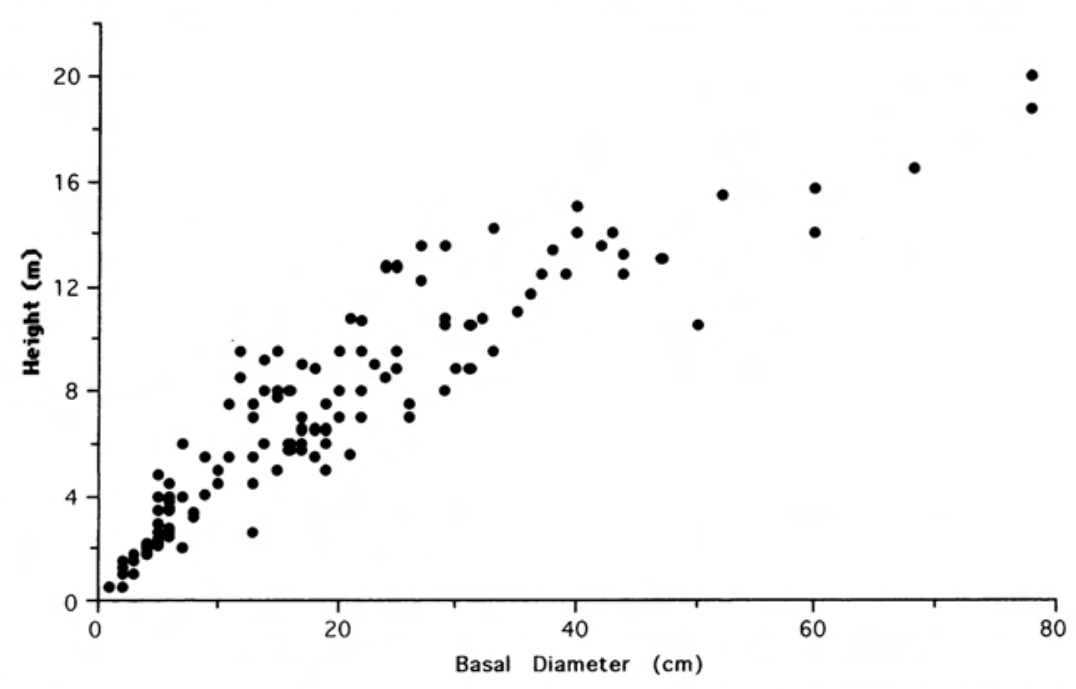

Fig. 1. Height plotted against basal diameter of Euphorbia ingens in Liwonde National Park, Malawi.

stuhlmannii. The first year (1994) the rhinoceros were in the park was an exceptionally dry year. The total rainfall recorded was $639 \mathrm{~mm}$. Average annual rainfall for Liwonde National Park is $853 \mathrm{~mm}$, S.D. 168 mm (Happold \& Happold 1990). For this reason, all natural water pools in the sanctuary dried up by the middle of July. However, an artificial waterhole surrounded by a muddy wallow was maintained near the boma throughout the year.

When the rhinoceros arrived at Liwonde, a programme to monitor the vegetation in the sanctuary was initiated. This programme is intended to build up baseline biological information to assist rhinoceros management. This paper reports on the effect of rhinoceros browse on $E$. ingens survival as well as the plant's possible influence on rhinoceros drinking habits.

\section{Euphorbia ingens}

The candelabra tree (E. ingens) is widely distributed in Malawi being found at medium to low altitudes in association with deciduous woodland, principally $C$. mopane in the Rift Valley and the lake shore plains (Coates Palgrave 1956). At maturity it is a massively branched tree (ingens = huge), some individuals have their branches forming a dense rounded crown. It is truly xerophytic, bearing only short lived rudimentary leaves, the greenish stems being photosynthetic. Each stem bears 4-5 flanges which are constricted to some degree in relation to annual growth patterns. Paired spines are scattered along the ridges. Like a number of other Euphorbia sp., the candelabra tree produces copious white latex which is extremely toxic, causing intense irritation and blistering to the skin (Coates Palgrave 1977).

This Euphorbia species is mostly limited to the western $10-20 \%$ of the park's woodland where, due to the extremely dense soil structure, conditions are exceptionally dry. But on the larger termite hills, this euphorbia is found in the Namalembo Thicket (deciduous forest/thicket) and over a wide area of the park's woodlands. It occasionally penetrates the edges of the riverine forest/thickets and a few specimens can be found on the inselbergs 
Table 1

Characteristics of browse damage to the candelabra tree by rhinoceros, Liwonde National Park, Malawi, September 1994 - August 1995

\begin{tabular}{lccccc}
\hline & Undamaged & $\begin{array}{c}\text { Pushed } \\
\text { over }\end{array}$ & $\begin{array}{c}\text { Broken } \\
\text { main stem }\end{array}$ & $\begin{array}{c}\text { Stem } \\
\text { feeding }\end{array}$ & Totals \\
\hline Number of plants sampled & 139 & 131 & 29 & 11 & 310 \\
Percent sampled by type & 44.8 & 42.3 & 9.4 & 3.5 & 100 \\
Number of plants killed & - & 131 & 9 & 0 & 140 \\
Percent mortality by type & - & 42.3 & 2.9 & 0 & 45.2 \\
& - & 8.8 & 5.0 & 12.0 & 10.7 \\
\hline Mean BD(cm) of browsed plants & - & 8.8 & 7.7 & & 8.7 \\
\hline Mean BD(cm) of killed plants & - & & & & \\
\hline
\end{tabular}

of the park. The species is only accidentally damaged by elephant browsing activity.

Some of the candelabra trees of Liwonde would appear to reach exceptional size. Figure 1 shows the heights of 136 specimens measured in Liwonde, along with their basal diameters (BD). The largest three specimens were selected from Namalembo Thicket (because of their great size), but the remaining were taken from fixed plots and transects within the mopane woodland complex of the sanctuary. Growth in height is quite closely associated with $\mathrm{BD}\left(\mathrm{r}^{2}=87 \%\right)$, particularly for the first 5 metres. The four specimens $>60 \mathrm{~cm} \mathrm{BD}$, are truly gigantic and all were found on large termite hills.

Coates Palgrave (1977) and Coates Palgrave (1956) state that in southern Africa the species reaches 35 feet $(10.5 \mathrm{~m})$ in height and 18 inches $(46 \mathrm{~cm})$ in BD. For E. candelabrum $(=E$. ingens) in southern Tanzania, Bjornstad (1976) and Vollesen (1980) record heights of 10-12 m.

\section{Discussion}

Very early after their release from the boma the rhinoceros began feeding upon the
E. ingens and this species has seen impressive destruction since January 1994. By June 1995, 18 months after the first monitoring plots were established, only four $E$. ingens under $20 \mathrm{~cm}$ BD remained of the 26 originally present in the plots. The feeding is wasteful as the rhinoceroses usually push the plants over and then feed upon some of the stems lying on the ground. This was of considerable concern since, once pushed over, the plant invariably dies.

A second succulent plant that began showing serious feeding signs as the dry season progressed in 1994 was the python vine, Fockea multiflora, a large latex-filled liana, common throughout the mopane woodlands. In the western section of the sanctuary, this large liana showed casual feeding at the bases of the larger specimens up to about $1.5 \mathrm{~m}$. Further to the east some of the plants have had most of their basal stem eaten away. None have died so far due to this damage. This species was only eaten in the dry season and again the copious latex did not deter feeding. Hall-Martin et al. (1982) report that rhinoceros in Addo ate F. edulis.

In August 1995, two west-east transects were laid out in the sanctuary, one $850 \mathrm{~m}$ 


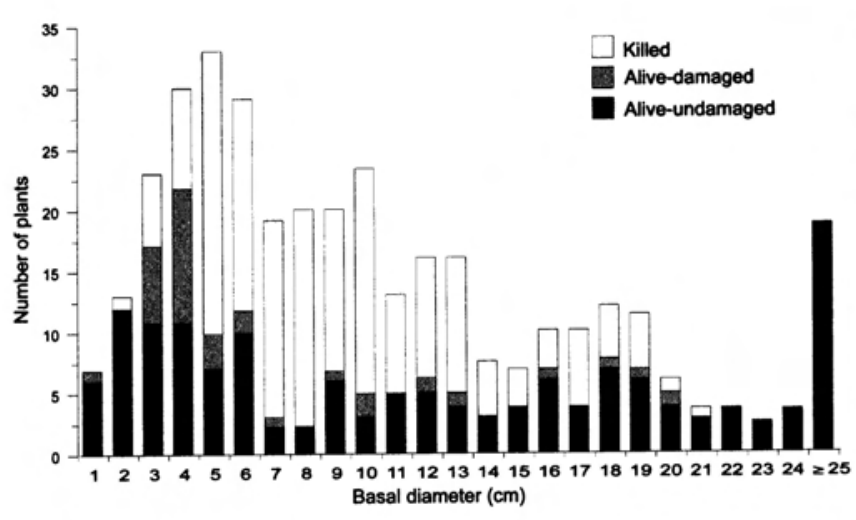

Fig. 2. The effect of rhinoceros browsing on Euphorbia ingens September 1994-August 1995, Liwonde National Park, Malawi. Transect and fixed plot data.

long, the other $425 \mathrm{~m}$. Within $25 \mathrm{~m}$ of either side of this transect, the height, BD and time and type of browse (if any) was recorded for each euphorbia, whether alive or dead. Euphorbias decay quickly and only evidence of the larger plants $(B D>10 \mathrm{~cm}$ ) remain after more than one year. Hence, only those plants thought to have been killed within the last 12 months were counted. Figures $2 \& 3$ and Table 1 show the results of this sample. Plants pushed over or broken at the base always died. Plant less than $6 \mathrm{~cm} \mathrm{BD}$ often survived through coppice regrowth if at least $50 \mathrm{~cm}$ of the basal stem remained. No mortality occurred where rhinoceros simply removed some of the bark of the main stems or larger branches. The average density for all euphorbia for the two transects was 55.5 plants per hectare.

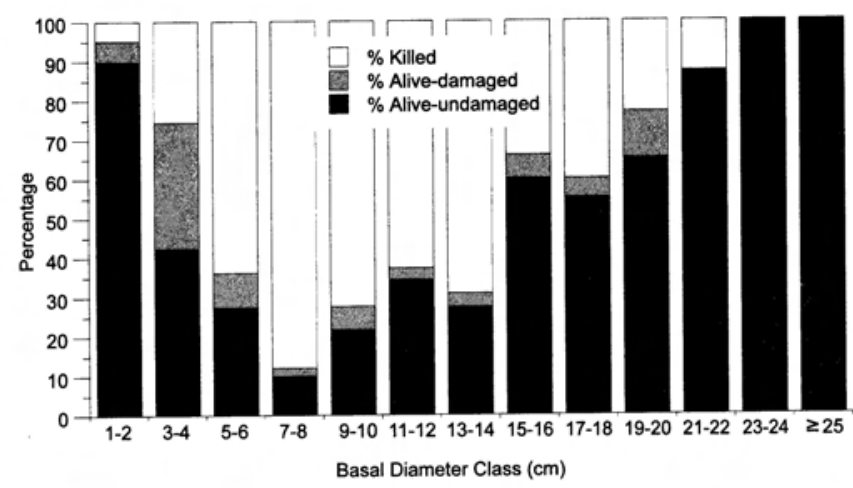

Fig. 3. Percentage mortality and damage to Euphorbia ingens due to rhinoceros browsing, September 1994-August 1995, Liwonde National Park, Malawi. Transect and plot data.
Approximately $45 \%$ of all plants recorded were killed within the twelve months period. The mortality rate declining rapidly with tree size, with no individuals $>21 \mathrm{~cm}$ BD killed. The small number of euphorbias found in the $1-3 \mathrm{~cm}$ BD category may be an effect of the difficulty in locating such small plants rather than any weakness in regeneration. The low percentage mortality, particularly in the two lowest classes, could well be a result of complete loss of the plant due to the browsing action of the rhinoceros.

The rhinoceros did not use the artificial water hole and wallow in the sanctuary either before or after the sun dried up all natural water holes by mid July 1994. The artificial waterhole was checked every day by the sanctuary guards and there was no evidence (spoor) that rhinoceros drank water from approximately 15 July until 31 October when the park had $26 \mathrm{~mm}$ of rain. Even then there was no evidence of drinking although this could have been missed as some small water holes remained with shallow water for about a week. There is a small herd of sable in the sanctuary $( \pm 23)$ and they did not use the artificial waterhole. As a consequence, eight died from lack of water as did one water buck and three impala. To correct this, two additional small tubs of water were put into the sanctuary during the 
first week in August near trails followed by sable. There were no further deaths. Scouts also checked the tubs every day and found no evidence that the rhonoceros used them until 23 September when one tub was turned over. Whether they drank or not is unknown.

Where did the rhinoceros get their water? I believe that $E$. ingens played an important role in providing moisture during the late dry season in 1994. While this species is extremely toxic, rhinoceros have been reported by others (Goddard 1968; Hargreaves 1978; Loutit et al. 1987; Lydekker 1926 (in Goddard 1968); Van Rensburg 1963) to feed on toxic latex bearing euphorbias such as E. turicalli and $E$. virosa. Goddard also noted that rhinoceros feed on other very toxic plants such as Datura stramonium. At Olduvai, E. turicalli was highly palatable to rhinoceros and eaten in great quantities making up $70 \%$ of the diet in the dry season. All parts were eaten, including the bark. Loutit et al. (1987) found that the desert rhinoceros fed on every $E$. virosa that was accessible to them in the locality and that the latex did not bother the animals. Hargreaves (1987) records baboon feeding on E. ingens in Malawi and Zimbabwe and I have observed similar feeding by baboon in Liwonde. Hargreaves (1995) also noted vervet monkeys ingesting latex from another Euphorbiaceae, Monadenium lugardae. It is obvious that some animals are relatively unaffected by latex.

Common knowledge says that rhinoceros need to drink often and wallow in mud to reduce the effects of sun and biting flies (Balfour \& Balfour 1991). Mukinya (1977) working in Kenya said that rhinoceros drank every day. Smithers (1983) says that they are dependent upon water and are seldom more than $10-15 \mathrm{~km}$ from it and, if water is available, drink daily. Cilliers (1989) said that rhinoceros in Etosha National Park drank every 72 hours and water was always present within one or two days walking time. In Namibia, Loutit et al. (1987) found that plants selected by rhinoceros varied considerably in their water content but this did not markedly influence their selection (except for $E$. virosa). They imply that rhinoceros regularly used natural water holes throughout the study period. At Addo (Hall-Martin 1982) and Ngorongoro National Parks (Goddard 1968) free water was always present and rhinoceros drank regularly. Adcock (1994) said that rhinoceros bulls will not establish regular territories more than about $10 \mathrm{~km}$ from water. Emslie \& Adcock (1994) wrote that black rhinoceros are dependent upon water and need to drink at least every third day, but preferably every day. Yet, the Bradley Martins (1982) state that Black rhinoceros can go for extended periods of time without free water, obtaining their requirements from plants. Goddard (1968), in Olduvai, found no evidence that animals took long walks for water but were attached to small home ranges even in the dry season when without water. He postulated that rhinoceros in very arid habitats can survive without free water, the rhinoceroses obtaining their water from euphorbias and other succulent plant species. He made no comment on the time period without free water.

I had discussions with the rhinoceros sanctuary guards in January 1996. They reported that they seldom saw any evidence of rhinoceros feeding on the euphorbias during the principal months of the rainy season (late December through early March). This agrees with my field observations in February 1996 where, after four hours of searching in the areas of my transects of 1995 I found no sign of rhinoceros feeding on this plant although there still were a number of individuals of suitable size.

While the two rhinoceros at Liwonde were able to comfortably survive through the long dry season without water due to their feeding 
upon succulents this does pose a problem for any future rhinoceros introductions into the sanctuary. By late 1996 the number of euphorbia within the feeding range of rhinoceros will be greatly reduced and then there may be a water problem. Consequently, although free water was not needed in 1994 with plenty of this succulent plant available, in the future when individuals of this species may be few and far between, a substantial water hole will be needed. As long as water is available browse does not appear to be a limiting factor.

\section{Acknowledgements}

The first year of the monitoring programme was supported by the South African High Commission and the Wildlife Society of Malawi. Most of the support was in material with some assistance with fuel. The rhinoceros introduction was made possible by the generous assistance of the South African Government through the Malawi/South Africa Wildlife Project, the J \& B Distilleries 'Care for the Rare' programme (U.K.), the J \& B Circle (Malawi) and the South African Air Force who transported the rhinoceros to Malawi. I wish to thank the Department of National Parks and Wildlife for allowing me access to both the park and the sanctuary for this study and to Roy Bhima, Research Officer, for providing information on mammal mortality within the sanctuary. Thanks also to my wife, Sandy Dudley, who assisted with gathering the field data.

\section{References}

ADCOCK, K. 1994. The relevance of "territorial" behaviour in black rhinoceros to their population management. Pp. 82-86. In: B.L. PENZHORN \& N.P.J. KRIEK (eds.) Proceedings of a Symposium on 'Rhinos as Game Ranch Animals' Onderstepoort 9 \& 10 September 1994.

Balfour, D. \& S. Balfour. 1991. Rhino. Cape Town: Struik.

BJORNSTAD, A. 1976. The vegetation of Ruaha National Park, Tanzania. I. Annotated check-list of the plant species. (Serengeti Research Institute Publication; no. 215.)

Bradley Martin, E. \& C. BRADley Martin 1982. Run rhinoceros run. London: Chatto \& Windus.

Cilliers, A. 1989. Diceros bicornis bicornis at Etosha National Park. Koedoe 32(2): 49-60).
Coates Palgrave, K. 1977. Trees of southern Africa. Cape Town: Struik.

Coates Palgrave, O. 1956. Trees of Central Africa. Salisbury: National Publication Trust Rhodesia and Nyasaland.

DuDLEY, C.O. 1994. The flora of Liwonde National Park, Malawi. Pp. 1485 - 1509. In: SEYANI, J.H. \& A.C. CHIKUNI (eds.). Proceedings of the XIIIth Plenary Meeting of AETFAT, Zomba, Malawi, 2-11 April 1991.

EMSLIE, R.H. \& K. ADCOCK. 1994. Managing black rhino. Pp. 100-107. In: PENZHORN, B.L. \& N.P.J. KrIEK (eds.). Proceedings of a Symposium on 'Rhinos as Game Ranch Animals' Onderstepoort 9 \& 10 September 1994.

GODDARD, J. 1968. Food preference of two black rhinoceros populations. East African Wildlife Journal 6: 1-18.

Hall-Martin, A.J., T ERASmus \& B.P. Botha. 1982. Seasonal variation of diet and faeces composition of black rhinoceros, Diceros bicornis, in the Addo Elephant National Park. Koedoe 25: 63-82.

HAPPOLD, D.C.D. \& M. HAPPOLD. 1990. An ecological study of small rodents in the woodland savanna of Liwonde National Park, Malawi. Journal of Zoology, London 221:219-235.

HARGREAVES, B.J. 1978. Rations and irration Succulent use in Kanye - Part III. Cactus and Succulent Journal (U.S.) 50:243.

Hargreaves, B.J. 1987. Succulent spurges of Malawi. Roma, Lesotho: Chilembwe Press.

HARGREAVES, B.J. 1995. The uses of Monadenium lugardae N.E. Brown. Euphorbiaceae Study Group Bulletin 8 (1):30-32.

LOUTIT, B.D., G.N. Louw \& M.K. SEely. 1987. First approximation of food preferences and the chemical composition of the diet of the desertdwelling black rhinoceros, Diceros bicornis L. Madoqua 15: 35-54.

LYDEKKER, R. 1926. The game animals of Africa. London: Rowland Ward.

MUKINYA, J.G. 1977. Feeding and drinking habits of the black rhinoceros in Masai Mara Game Reserve. East African Wildlife Journal 15: 125138.

SMITHERS, R.H.N. 1983. The mammals of the southern African subregion. Pretoria: University of Pretoria Press.

VAN RENSBURG, H.J. 1963. Ecological research as a basis for management. Conservation of Nature and Natural Resources in Modern African States. IUCN symposium, Arusha.

VOLLESEN, K. 1980. Annotated check-list of the vascular plants of the Selous Game Reserve, Tanzania. Opera botanica 59: 1-117. 